\title{
ЗАБІЙНІ ЯКОСТІ СВИНЕЙ РІЗНИХ ГЕНОТИПІВ
}

Бірта Габріелла Олександрівна

доктор сільськогосподарських наук, професор

Вищий навчальний заклад Укоопспілки

«Полтавський університет економіки і торгівлі»

ORCID: 0000-0001-6952-7554

E-mail: birta2805@gmail.com

Бургу Юрій Георгійович

кандидат сільськогосподарських наук, доцент

Вищий навчальний заклад Укоопспілки «Полтавський університет економіки і торгівлі» ORCID: 0000-0003-0560-1203 E-mail: byrgy1973@gmail.com

Флока Людмила Валеріївна кандидат сільськогосподарських наук, доцент

Вищий навчальний заклад Укоопспілки «Полтавський університет економіки і торгівлі» ORCID: 0000-0001-5429-2924 E-mail: flokaliudmyla@gmail.com

Горячова Олена Олександрівна кандидат технічних наук, доцент Вищий навчальний заклад Укоопспілки «Полтавський університет економіки і торгівлі» ORCID: 0000-0002-0424-4198 E-mail: goryachova0ea@gmail.com

Хмельницька Євгенія Вікторівна кандидат технічних наук, доцент Вищий навчальний заклад Укоопспілки «Полтавський університет економіки і торгівлі» ORCID: 0000-0002-2513-3032 E-mail: evghme37112@gmail.com

В статmі досліджено забійні та м'ясо-сальні якості тварин різних генотипів. Було визначено наступні показники: передзабійна маса; забійна маса; забійний вихід; довжина напівтуші; товщина шпику; площа «м'язового вічка»; вихід м'яса і сала в туші, морфологічний склад туш, масу м'язової тканини. На основі одержаних експериментальних даних проведено дисперсійний аналіз впливу форм годівлі на забійні якості свиней. В середньому по досліду загальна дисперсія, що показує загальну мінливість ознаки при забої свиней живою масою 100 ке, коливалась від 0,93 у свиней миргородської породи до 1,01 у полтавської м'ясної породи. Найбільшою частка впливу форми годівлі на забійний вихід спостерігалась у свиней м'ясних генотипів, зокрема у полтавської м'ясної 84,9-88,8\% та червоної білопоясої породи свиней 86,4-83,6\%. Результати забою засвідчили перевагу м'ясних генотипів над представниками сальних і м'ясо-сальних порід за показниками забійного виходу, довжини напівтуші, товщини шпику та маси окосту. В сучасних умовах виробництва свинини відгодівля тварин потребує врахування певних проблем, пов'язаних із впливом умов утримання, повноцінної годівлі, статі та результативності виробництва - середньодобові прирости, товщину шпику, витрати корму на одиницю продукції. Відгодівлю свиней різної статі необхідно організовувати відповідно до їх потреби у поживних речовинах.

Ключові слова: забій, якість, морфологічний склад, генотип, годівля, свинарство

DOI: https://doi.org/10.32845/bsnau.Ivst.2021.4.11

Значна роль в забезпеченні населення України м'ясними продуктами відводиться, насамперед, свинарству як найбільш інтенсивної галузі тваринництва. В сучасних умовах ринкової економіки дуже важливо перевести існуючі комплекси і свиноферми на інтенсивну технологію з закінченим циклом виробництва свиней.

Успішний розвиток галузі і конкурентоспроможність продукції свинарства багато в чому залежать від рівня се- лекційно-генетичної роботи і технології виробництва [1].

Свинарство - це найважливіша галузь тваринництва, яка вирішує стратегічні завдання щодо забезпечення населення м'ясними продуктами повноцінного білкового походження[4].

Головним завданням племінної роботи в свинарстві на сучасному етапі $€$ вдосконалення господарсько-корисних ознак свиней, з метою отримання від них максимальної про-

Вісник Сумського національного аграрного університету 
дукції в умовах промислової технології [2].

Залежно від статі забійних тварин одержують три види м'яса: м'ясо кнурів, м'ясо кастратів і м'ясо самок, яке суттєво відрізняється одне від одного за морфологічним та хімічним складом, а також смаковими якостями.

Для м'яса некастрованих тварин характеристика наявність в м'язовій тканині грубих і жорстких волокон. Відсутні жирові відкладення між м'язами. М'ясо некастрованих тварин звичайно більш темного кольору, специфічного запаху, який при варінні посилюється. Запах м'яса кнурів зникає при солінні [3].

М'ясо кастрованих самців більш ніжне, ніж некастрованих, 3 жировими відкладеннями між м'язовими волокнами. М'ясо цих тварин не має специфічного запаху і більш світлого кольору. М'ясо самок більш ніжне, з тонкою волокнистістю і має більш світле забарвлення. Жирові відкладення спостерігаються переважно між м'язами [4].

Стать тварин впливає і на хімічний склад м'яса. В м'ясі некастрованих тварин міститься більше екстрактивних речовин. Наприклад, каріозину вдвічі більше, ніж в м'ясі самок. В м'ясі самок, навпаки, міститься більше глікогену, ніж в м'ясі самців. Всі ці фактори суттєво впливають на якість м'яса [5].

В зв'язку із зростаючими вимогами внутрішнього ринку в нашій країні на нежирну свинину в останні роки різко змінився напрямок в розвитку свинарства. Зусилля вчених $і$ виробничників тепер спрямовані на створення нових і удосконалення існуючих порід свиней з підвищеною м'ясністю, на розробку відповідних умов годівлі та утримання тварин, вивчення кормових норм і раціонів та ін. Поряд з цим виникає інтерес щодо можливостей використання для відгодівлі кнурців. До цього часу всіх кнурців, виділених для відгодівлі, як правило, каструють у віці до одного місяця [6].

Відомо, що у кастрованих самців внаслідок припинення сперматогенної і гормональної функції статевих залоз затримується ріст і розвиток. Кастровані кнурці в зв'язку з виключенням міогенної дії їх статевих гормонів стають більш податливими до ожиріння.

В свій час відгодовували свиней, щоб одержувати більше жиру (сала), і тоді кастрація кнурців мала своє значення і була обгрунтованою. Тепер, в зв'язку з завданням виробляти більше м'ясної свинини застосування методів, що сприяють ожирінню тварин, втрачає своє виробниче значення [7].

Тому виникла необхідність точних дослідів для вивчення ефективності відгодівлі кнурців і кастратів, виявити можливі зміни при цьому в обміні речовин, приростах живої маси, оплаті корму, виходах м'ясо-сальної продукції та її якості [8].

В зоотехнічній літературі наведені повідомлення про проведений експеримент щодо м'ясних якостей кнурців. Цей дослід показав, що до 7-місячного віку жива маса кнурців і кабанчиків була майже однакова - кабанчики важили 75,4 , а кнурці - 76,2 кг. На 100 кг охолодженої туші кабанчиків припадало сала 32,9 і м'яса 65,4 кг, а в тушах кнурців було відповідно 25,8 і 72,3. Таким чином, у тушах кнурців порівняно 3 кабанчиками було більше м'яса на $6,9 \%$ і менше сала на $6,5 \%$. В сухій речовині м'яса кабанчиків жир становив 29,16 , кнурців - 21,26\% (при однаковій кількості білка) [9].

Цікаві дані одержано в дослідах американських вчених. Ці досліди показали, що кнурці досягли живої маси 90,7 кг у віці 148, а кабанчики - 147 днів. Товщина сала у кнурців 3,15 , а у кабанчиків $-3,45$ см. Автори прийшли до висновку, що при відгодівлі каструвати кнурців не обов'язково [10].

Доведено, що свинки при відгодівлі дають менший приріст, ніж кастрати, але вигідно відрізняються від них кращими м'ясними формами, більш тонким вирівняним шпиком і більшим вмістом м'яса в туші. У свинок на відгодівлі середньодобовий приріст становить 628 г, довжина туш - 93 см, товщина підшкірного жиру - 34,8 мм, площа м'язового вічка - 31,8 см², у кастратів ці показники дорівнюють відповідно 646 г, 92,4 см, 37,2 мм і 30,3 см². Отже, свинки мають кращі м'ясні та беконні якості [11].

Дослідження відгодівельної і м'ясної продуктивності некастрованих кнурців, кастратів і свинок показали, що при м'ясній відгодівлі від 20 до 90кг кнурці краще (на 8,3\%) росли, ніж кастрати, і менше (на 3,7\%) витрачали корму на приріст маси. Свинки використовували корм гірше кнурців, але краще від кастратів. Краща м'ясність туш була у кнурців [12].

Деякі вчені рекомендують відмовитися від кастрації поросят, яких використовують для інтенсивної м'ясної відгодівлі, якщо вони досягають забійної маси не пізніше 5,5місячного віку. На їх думку, внаслідок дії статевих гормонів підвищується ефрективність засвоєння кормів і м'ясна продуктивність [13]

Дослідження вітчизняних та зарубіжних авторів свідчать, що при інтенсивній відгодівлі не кастрованих кнурів до живої маси 90-100кг підвищуються середньодобові прирости на 5-10\%, вихід м'яса в тушах збільшується на $3-5 \%$ і знижуються витрати корму. Проте ефективність відгодівлі кнурців різних генотипів вивчена недостатньо. Цей метод у даний час на виробництві майже не застосовується [14].

В умовах можливості регулювання співвідношення статі викликає інтерес вивчення господарськи корисних та біологічних особливостей тварин різних статей і ефеективність застосування їх для виробництва більш дешевої продукції тваринництва при чистопородному розведенні та схрещуванні в різних умовах зовнішнього середовища.

Матеріали та методи дослідження. В дослідах використані тварини чистопородного свинопоголів'я великої білої породи (ВБ), миргородської (М), полтавської м'ясної (ПМ), ландрас (Л) та червоної білопоясої (ЧБП) породи м'ясних свиней. Забійні та м'ясо-сальні якості тварин визначалися за наступними показниками: передзабійна маса; забійна маса; забійний вихід; довжина напівтуші; товщина шпику; площа «м'язового вічка»; вихід м'яса і сала в туші. Дослідження здійснювали у відповідності до стандартних методичних вказівок. Морфологічний склад туш вивчали шляхом обвалки правої напівтуші. Масу м'язової тканини визначали по різниці між масою напівтуші і сумарної маси сала та кісток [15].

Після досягнення поросятами середньої живої маси 30 кг формували за принципом аналогів піддослідні групи зі свинок, кнурців та кастратів для подальшого порівняльного вивчення їх розвитку при різних рівнях відгодівлі до живої маси 100 і 125 кг. Утримували тварин групами по 10-12 голів в станку

Результати дослідження та обговорення. Результати наших досліджень дозволили встановити характер впливу генотипового та паратипового факторів на забійні якості тварин.

Контрольний забій піддослідних підсвинків при сере- 
дньодобових приростах 250-350 г показав, що тварини м'ясних генотипів (III, IV, V груп) мали явні переваги в порівнянні 3 аналогами I та II груп (табл.1).

Найвищі показники забійного виходу мали тварини полтавської м'ясної породи і ландрас: відповідно 70,9 і 70,7\% при 100 кг і 71,6-72,1\% при 125 кг. Вони переважали тварин миргородської породи на 2,7-2,9\% при забої в 100 кг на 2,4-2,9 \% - в 125 кг. Довжина півтуші виявилася стабільною типовою ознакою і залежала від генотипу піддослідних тварин. Найдовшими виявились туші породи ландрас: в середньому 96,0-100,0 см, а найкоротшими - миргородської породи - 91,9-93,4 см.

Таблиця 1

Забійні якості піддослідних свиней (середньодобовий приріст 250-350 г)

\begin{tabular}{|c|c|c|c|c|c|c|c|c|c|c|c|c|c|c|}
\hline \multirow{2}{*}{ 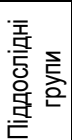 } & \multirow{2}{*}{$\begin{array}{l}\text { 흥 } \\
\text { 음 }\end{array}$} & \multirow{2}{*}{$\begin{array}{c}\text { Статева } \\
\text { належність } \\
\text { тварин }\end{array}$} & \multicolumn{2}{|c|}{$\begin{array}{c}\text { Передзабійна } \\
\text { маса, кг }\end{array}$} & \multicolumn{2}{|c|}{$\begin{array}{l}\text { Забійна } \\
\text { маса, кг }\end{array}$} & \multicolumn{2}{|c|}{$\begin{array}{l}\text { Забійний } \\
\text { вихід, \% }\end{array}$} & \multicolumn{2}{|c|}{$\begin{array}{c}\text { Довжина } \\
\text { напівтуші, см }\end{array}$} & \multicolumn{2}{|c|}{$\begin{array}{c}\text { Товщина шпику } \\
\text { над 6-7 грудним } \\
\text { хребцем мм } \\
\end{array}$} & \multicolumn{2}{|c|}{ Маса окосту, кг } \\
\hline & & & $100 \mathrm{kr}$ & $125 \mathrm{kr}$ & $100 \mathrm{kг}$ & $125 \mathrm{kr}$ & $100 \mathrm{kr}$ & 125 кг & $100 \mathrm{kr}$ & $125 \mathrm{kг}$ & $100 \mathrm{kr}$ & $125 \mathrm{k \Gamma}$ & $100 \mathrm{kr}$ & $125 \mathrm{kr}$ \\
\hline \multirow{4}{*}{ I } & \multirow{4}{*}{ ВБ } & Свинки & $\begin{array}{c}99,7 \pm \\
0,99\end{array}$ & \begin{tabular}{|c|}
$123,6 \pm$ \\
0,89
\end{tabular} & $\begin{array}{c}68,4 \pm \\
1,23 \\
\end{array}$ & $\begin{array}{c}86,1 \pm \\
1,32\end{array}$ & $\begin{array}{c}68,6 \pm \\
0,88\end{array}$ & $\begin{array}{c}69,7 \pm \\
0,78 \\
\end{array}$ & $\begin{array}{c}91,9 \pm \\
2,08\end{array}$ & $\begin{array}{c}94,6 \pm \\
1,31\end{array}$ & $\begin{array}{c}36,1 \pm \\
0,69\end{array}$ & $\begin{array}{c}37,7 \pm \\
0,49\end{array}$ & $\begin{array}{c}10,3 \pm \\
0,36 \\
\end{array}$ & $\begin{array}{c}11,7 \pm \\
0,62 \\
\end{array}$ \\
\hline & & Кастрати & $\begin{array}{c}101,2 \pm \\
1,36 \\
\end{array}$ & \begin{tabular}{|c|}
$125,4 \pm$ \\
1,23 \\
\end{tabular} & $\begin{array}{c}70,0 \pm \\
0,96\end{array}$ & $\begin{array}{c}88,8 \pm \\
0,99\end{array}$ & $\begin{array}{c}69,1 \pm \\
0,59\end{array}$ & $\begin{array}{c}70,8 \pm \\
1,11 \\
\end{array}$ & $\begin{array}{c}93,0 \pm \\
0,99\end{array}$ & $\begin{array}{c}96,5 \pm \\
1,65 \\
\end{array}$ & $\begin{array}{c}37,3 \pm \\
0,33\end{array}$ & $\begin{array}{c}38,9 \pm \\
0,21\end{array}$ & $\begin{array}{c}10,5 \pm \\
0,32 \\
\end{array}$ & $\begin{array}{c}12,3 \pm \\
0,36 \\
\end{array}$ \\
\hline & & Кнурці & $\begin{array}{c}100,3 \pm \\
1,68 \\
\end{array}$ & $\begin{array}{c}124,8 \pm \\
0,99 \\
\end{array}$ & $\begin{array}{c}68,9 \pm \\
0,64\end{array}$ & $\begin{array}{c}87,9 \pm \\
0,68\end{array}$ & $\begin{array}{c}68,7 \pm \\
0,45\end{array}$ & $\begin{array}{c}70,5 \pm \\
0,88 \\
\end{array}$ & $\begin{array}{c}93,3 \pm \\
0,89 \\
\end{array}$ & $\begin{array}{c}96,8 \pm \\
0,99 \\
\end{array}$ & $\begin{array}{c}36,0 \pm \\
0,36\end{array}$ & $\begin{array}{c}37,4 \pm \\
0,15\end{array}$ & $\begin{array}{c}10,7 \pm \\
0,26 \\
\end{array}$ & $\begin{array}{c}12,1 \pm \\
0,51 \\
\end{array}$ \\
\hline & & В середньому & 100,4 & 124,6 & 69,1 & 87,6 & 68,8 & 70,3 & 92,7 & 96,0 & 36,5 & 38,0 & 10,5 & 12,0 \\
\hline \multirow{4}{*}{ ॥ } & \multirow{4}{*}{ M } & Свинки & $\begin{array}{c}100,8 \pm \\
2,02\end{array}$ & $\begin{array}{c}124,8 \pm \\
1,36\end{array}$ & $\begin{array}{c}67,9 \pm \\
0,58\end{array}$ & $\begin{array}{c}84,9 \pm \\
1,36\end{array}$ & $\begin{array}{c}67,3 \pm \\
1,03\end{array}$ & $\begin{array}{c}68,0 \pm \\
0,69\end{array}$ & $\begin{array}{c}90,9 \pm \\
1,36\end{array}$ & $\begin{array}{c}92,8 \pm \\
1,25\end{array}$ & $\begin{array}{c}38,4 \pm \\
0,26\end{array}$ & $\begin{array}{c}42,9 \pm \\
0,12\end{array}$ & $\begin{array}{c}10,3 \pm \\
0,24\end{array}$ & $\begin{array}{l}11,5^{* *} \\
\pm 0,34\end{array}$ \\
\hline & & Кастрати & $\begin{array}{c}101,3 \pm \\
0,98\end{array}$ & $\begin{array}{c}126,1 \pm \\
1,65\end{array}$ & $\begin{array}{c}69,4 \pm \\
0,66\end{array}$ & $\begin{array}{c}87,9 \pm \\
0,89\end{array}$ & $\begin{array}{c}68,5 \pm \\
0,56\end{array}$ & $\begin{array}{c}69,7 \pm \\
0,59\end{array}$ & $\begin{array}{c}92,1 \pm \\
0,69\end{array}$ & $\begin{array}{c}93,3 \pm \\
1,22\end{array}$ & $\begin{array}{c}39,0 \pm \\
0,62\end{array}$ & $\begin{array}{c}43,5 \pm \\
0,22\end{array}$ & $\begin{array}{c}10,6 \pm \\
0,32 \\
\end{array}$ & $\begin{array}{c}12,5 \pm \\
0,26 \\
\end{array}$ \\
\hline & & Кнурці & $\begin{array}{c}100,2 \pm \\
1,11 \\
\end{array}$ & $\begin{array}{c}125,7 \pm \\
2,61\end{array}$ & $\begin{array}{c}68,2 \pm \\
1,36\end{array}$ & $\begin{array}{c}87,9 \pm \\
1,11\end{array}$ & $\begin{array}{c}68,1 \pm \\
1,69\end{array}$ & $\begin{array}{c}69,9 \pm \\
0,88\end{array}$ & $\begin{array}{c}92,7^{*} \pm \\
1,59\end{array}$ & $\begin{array}{c}94,2 \pm \\
1,33\end{array}$ & $\begin{array}{c}38,0 \pm \\
0,34\end{array}$ & $\begin{array}{c}42,0^{*} \pm \\
0,19\end{array}$ & $\begin{array}{c}10,7 \pm \\
0,14\end{array}$ & $\begin{array}{c}12,4 \pm \\
0,31\end{array}$ \\
\hline & & В середньому & 100,8 & 125,5 & 68,5 & 86,9 & 68,0 & 69,2 & 91,9 & 93,4 & 38,5 & 42,8 & 10,5 & 12,1 \\
\hline \multirow{4}{*}{ III } & \multirow{4}{*}{ Л } & Свинки & $\begin{array}{c}101,2 \pm \\
2,21\end{array}$ & $\begin{array}{c}125,3 \pm \\
2,31\end{array}$ & $\begin{array}{c}71,0 \pm \\
1,23\end{array}$ & $\begin{array}{c}88,9 \pm \\
2,09\end{array}$ & $\begin{array}{c}70,2 \pm \\
1,33\end{array}$ & $\begin{array}{c}71,0 \pm \\
1,35\end{array}$ & $\begin{array}{c}94,7 \pm \\
0,68\end{array}$ & $\begin{array}{c}98,4 \pm \\
0,96\end{array}$ & $\begin{array}{c}33,1 \pm \\
0,84\end{array}$ & $\begin{array}{c}34,8 \pm \\
0,22\end{array}$ & $\begin{array}{c}11,8^{*} \pm \\
0,24\end{array}$ & $\begin{array}{c}13,6 \pm \\
0,51\end{array}$ \\
\hline & & Кастрати & $\begin{array}{c}100,5 \pm \\
0,69\end{array}$ & \begin{tabular}{|c|}
$126,4 \pm$ \\
1,69 \\
\end{tabular} & $\begin{array}{c}71,3 \pm \\
0,89\end{array}$ & $\begin{array}{c}91,1 \pm \\
0,69\end{array}$ & $\begin{array}{c}71,0 \pm \\
2,56\end{array}$ & $\begin{array}{c}72,1 \pm \\
1,62 \\
\end{array}$ & $\begin{array}{c}96,4 \pm \\
2,31 \\
\end{array}$ & $\begin{array}{c}100,3 \pm \\
0,98\end{array}$ & $\begin{array}{c}33,7 \pm \\
0,26\end{array}$ & $\begin{array}{c}35,6 \pm \\
0,18\end{array}$ & $\begin{array}{c}12,1 \pm \\
0,12 \\
\end{array}$ & \begin{tabular}{|c|}
$13,6 \pm$ \\
0,29 \\
\end{tabular} \\
\hline & & Кнурці & $\begin{array}{c}99,7 \pm \\
2,03 \\
\end{array}$ & $\begin{array}{c}127,1 \pm \\
2,31 \\
\end{array}$ & $\begin{array}{c}70,8 \pm \\
0,66 \\
\end{array}$ & $\begin{array}{c}91,2 \pm \\
1,59\end{array}$ & $\begin{array}{c}71,0 \pm \\
0,64 \\
\end{array}$ & $\begin{array}{c}71,7 \pm \\
1,23 \\
\end{array}$ & $\begin{array}{c}96,9 \pm \\
2,25\end{array}$ & $\begin{array}{c}101,3 \pm \\
0,32 \\
\end{array}$ & $\begin{array}{c}33,2 \pm \\
0,68 \\
\end{array}$ & $\begin{array}{l}35,1^{* *} \\
\pm 0,22 \\
\end{array}$ & $\begin{array}{c}12,3 \pm \\
0,52 \\
\end{array}$ & $\begin{array}{l}13,4^{* *} \\
\pm 0,36 \\
\end{array}$ \\
\hline & & В середньому & 100,5 & 126,2 & 71,1 & 90,4 & 70,7 & 71,6 & 96,0 & 100,0 & 33,3 & 35,2 & 12,1 & 13,5 \\
\hline \multirow{4}{*}{ IV } & \multirow{4}{*}{ ПМ } & Свинки & $\begin{array}{c}99,7 \pm \\
1,24\end{array}$ & $\begin{array}{c}123,4 \pm \\
2,05\end{array}$ & $\begin{array}{c}70,3 \pm \\
0,85\end{array}$ & $\begin{array}{c}88,2 \pm \\
0,69\end{array}$ & $\begin{array}{c}70,5 \pm \\
0,88\end{array}$ & $\begin{array}{c}71,5 \pm \\
0,68\end{array}$ & $\begin{array}{c}94,1 \pm \\
1,11\end{array}$ & $\begin{array}{c}97,6 \pm \\
0,69\end{array}$ & $\begin{array}{c}32,5 \pm \\
0,21\end{array}$ & $\begin{array}{c}35,3 \pm \\
0,21\end{array}$ & $\begin{array}{c}11,6 \pm \\
0,26\end{array}$ & $\begin{array}{c}13,1 \pm \\
0,29 \\
\end{array}$ \\
\hline & & Кастрати & $\begin{array}{c}102,8 \pm \\
2,02\end{array}$ & $\begin{array}{c}127,7 \pm \\
0,69\end{array}$ & $\begin{array}{c}73,3 \pm \\
2,11\end{array}$ & $\begin{array}{c}93,3 \pm \\
2,36\end{array}$ & $\begin{array}{c}71,3 \pm \\
1,25\end{array}$ & $\begin{array}{c}73,1 \pm \\
0,95\end{array}$ & $\begin{array}{c}95,8 \pm \\
1,23\end{array}$ & $\begin{array}{c}98,4 \pm \\
0,69\end{array}$ & $\begin{array}{c}33,0^{* *} \pm \\
0,15\end{array}$ & $\begin{array}{c}35,8 \pm \\
0,13\end{array}$ & $\begin{array}{c}11,5 \pm \\
0,32\end{array}$ & $\begin{array}{c}13,5 \pm \\
0,13\end{array}$ \\
\hline & & Кнурці & $\begin{array}{c}102,6 \pm \\
1,03 \\
\end{array}$ & $\begin{array}{c}126,1 \pm \\
1,06 \\
\end{array}$ & \begin{tabular}{|c|}
$72,7 \pm$ \\
1,21 \\
\end{tabular} & $\begin{array}{c}90,3 \pm \\
2,05 \\
\end{array}$ & $\begin{array}{c}70,9 \pm \\
0,69 \\
\end{array}$ & \begin{tabular}{|c|}
$71,7 \pm$ \\
1,21 \\
\end{tabular} & \begin{tabular}{|c|}
$95,8 \pm$ \\
1,31 \\
\end{tabular} & $\begin{array}{c}99,2^{* *} \pm \\
1,61 \\
\end{array}$ & $\begin{array}{c}32,3 \pm \\
0,21 \\
\end{array}$ & \begin{tabular}{|c|}
$35,2 \pm$ \\
0,26 \\
\end{tabular} & $\begin{array}{c}11,8 \pm \\
0,16 \\
\end{array}$ & \begin{tabular}{|c|}
$13,4 \pm$ \\
0,21 \\
\end{tabular} \\
\hline & & В середньому & 101,7 & 125,4 & 72,1 & 90,6 & 70,9 & 72,1 & 95,3 & 98,4 & 32,6 & 35,4 & 11,6 & 13,3 \\
\hline \multirow{4}{*}{ V } & \multirow{4}{*}{ ЧБП } & Св & $\begin{array}{c}101,3 \pm \\
0,98 \\
\end{array}$ & \begin{tabular}{|c|}
$126,4 \pm$ \\
1,06 \\
\end{tabular} & \begin{tabular}{|c|}
$69,6 \pm$ \\
0,87
\end{tabular} & $\begin{array}{c}88,9 \pm \\
0,88\end{array}$ & $\begin{array}{c}68,7 \pm \\
1,25 \\
\end{array}$ & \begin{tabular}{|c|}
$70,3 \pm$ \\
0,56
\end{tabular} & $\begin{array}{c}93,6 \pm \\
0,98 \\
\end{array}$ & \begin{tabular}{|c|}
$97,1 \pm$ \\
0,95 \\
\end{tabular} & $\begin{array}{c}31,6^{\star *} \pm \\
0,16\end{array}$ & $\begin{array}{c}33,8 \pm \\
0,21 \\
\end{array}$ & $11,5^{* *} \pm 0,32$ & $\begin{array}{c}13,0 \pm \\
0,16 \\
\end{array}$ \\
\hline & & Кастрати & $\begin{array}{c}102,4 \pm \\
1,12\end{array}$ & $\begin{array}{c}126,5 \pm \\
2,03\end{array}$ & $\begin{array}{c}72,3 \pm \\
0,89\end{array}$ & $\begin{array}{c}90,4 \pm \\
1,65\end{array}$ & $\begin{array}{c}70,6 \pm \\
0,89\end{array}$ & $\begin{array}{c}71,5 \pm \\
1,26\end{array}$ & $\begin{array}{c}95,3 \pm \\
1,39\end{array}$ & $\begin{array}{c}98,3 \pm \\
1,32\end{array}$ & $\begin{array}{c}32,4 \pm \\
0,11\end{array}$ & $\begin{array}{l}35,6^{* *} \\
\pm 0,14\end{array}$ & $\begin{array}{c}11,7 \pm \\
0,19\end{array}$ & $\begin{array}{l}13,5^{* *} \\
\pm 0,34\end{array}$ \\
\hline & & Кнурці & $\begin{array}{c}102,9 \pm \\
2,03\end{array}$ & $\begin{array}{c}126,3 \pm \\
0,99\end{array}$ & $\begin{array}{c}71,8 \pm \\
1,23\end{array}$ & $\begin{array}{c}89,3 \pm \\
1,29\end{array}$ & $\begin{array}{c}69,8 \pm \\
0,69\end{array}$ & $\begin{array}{c}70,7 \pm \\
0,58 \\
\end{array}$ & $\begin{array}{c}96,0 \pm \\
1,61\end{array}$ & $\begin{array}{c}99,0^{*} \pm \\
0,85\end{array}$ & $\begin{array}{c}32,0 \\
\pm 0,18 \\
\end{array}$ & $\begin{array}{l}35,1^{* *} \\
\pm 0,19\end{array}$ & $\begin{array}{c}11,4^{*} \\
\pm 0,12\end{array}$ & $\begin{array}{c}13,1 \pm \\
0,41\end{array}$ \\
\hline & & В середньому & 102,2 & 126,4 & 71,2 & 89,5 & 69,7 & 70,8 & 95,0 & 98,1 & 32,0 & 34,8 & 11,5 & 13,2 \\
\hline \multicolumn{3}{|c|}{3 середньому по досліду } & 101,1 & 125,6 & 70,4 & 89,0 & 69,6 & 70,8 & 94,2 & 97,2 & 34,6 & 37,3 & 11,2 & 12,8 \\
\hline
\end{tabular}

Примітка: ${ }^{*}-P \leq 0,05 ;{ }^{* *}-P \leq 0,01$

Найбільша товщина шпику відмічалась у молодняку II групи і становила 38,5 мм у 100 кг та 42,8 мм - 125 кг.

За масою задньої третини напівтуші найкращі показники мали тварини III піддослідної групи. У них вона при забої у 100 кг становила 12,1 кг; збільшення живої маси призвело до збільшення маси окосту по групах в середньому на 1,5 кг.

Що стосується статевої різниці, отримані дані підтвердили результати інших дослідників. Кастрати не поступались свинкам за довжиною туші, масою окоста; туші кастратів характеризувались дещо більшою товщиною шпику.

Позитивний вплив статевих гормонів на м'ясність туш проявився у свиней всіх порід: кнурці в порівнянні з кастратами мали довші туші і меншу товщину шпику.
Збільшення середньодобових приростів призвело до покращення забійних якостей. При цьому тенденція до отримання кращих забійних якостей у тварин м'ясних генотипів зберігалась і стала більш суттєвою (табл.2).

Свині породи ландрас були найдовшими і мали найбільший забійний вихід та масу окосту. Майже не поступались їм свині полтавської м'ясної породи. Тварини червоної білопоясої породи мали найменшу товщину шпику 30,132,8 мм, що на 5,2-5,8 мм менше ніж у миргородської породи, де цей показник виявився найбільшим.

При середньодобових приростах 800-1000 г середні показники забійного виходу при забої в 100 і 125 кг склали 71,2-72,9\%, що на 0,3-0,5 \% більше ніж при середньодобових приростах 600-800 г і на 2,1\% - при середньодобових 
3абійні якості піддослідних свиней (середньодобовий приріст 600-800 г)

\begin{tabular}{|c|c|c|c|c|c|c|c|c|c|c|c|c|c|c|}
\hline \multirow{2}{*}{ 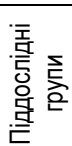 } & \multirow{2}{*}{$\begin{array}{l}\text { 홍 } \\
\text { 음 }\end{array}$} & \multirow{2}{*}{$\begin{array}{c}\text { Статева } \\
\text { належність } \\
\text { тварин }\end{array}$} & \multicolumn{2}{|c|}{$\begin{array}{c}\text { Передзабійна маса, } \\
\text { кг }\end{array}$} & \multicolumn{2}{|c|}{ Забійна маса, кг } & \multicolumn{2}{|c|}{$\begin{array}{c}\text { Забійний вихід, } \\
\%\end{array}$} & \multicolumn{2}{|c|}{$\begin{array}{c}\text { Довжина } \\
\text { напівтуші, см }\end{array}$} & \multicolumn{2}{|c|}{\begin{tabular}{|c|} 
Товщина шпику над \\
6-7 грудним \\
хребцем мм \\
\end{tabular}} & \multicolumn{2}{|c|}{ Маса окосту, кг } \\
\hline & & & 100 кг & 125 кг & $100 \mathrm{kr}$ & 125 кг & 100 кг & 125 кг & 100 кг & $125 \mathrm{kr}$ & 100 кг & 125 кг & 100 кг & 125 кг \\
\hline \multirow{4}{*}{ I } & \multirow{4}{*}{ BБ } & Свинки & $\begin{array}{c}99,8 \pm \\
0,99 \\
\end{array}$ & $\begin{array}{c}125,1 \pm \\
2,31\end{array}$ & $\begin{array}{c}69,2 \pm \\
2,01\end{array}$ & $\begin{array}{c}88,1 \pm \\
0,87\end{array}$ & $\begin{array}{c}69,3 \pm \\
1,36 \\
\end{array}$ & $\begin{array}{c}70,4 \pm \\
1,23 \\
\end{array}$ & $\begin{array}{c}92,8 \pm \\
2,06\end{array}$ & $\begin{array}{c}95,6 \pm \\
1,23\end{array}$ & $\begin{array}{c}34,1 \pm \\
0,12\end{array}$ & $\begin{array}{c}35,6 \pm \\
0,21\end{array}$ & $\begin{array}{c}10,4 \pm \\
0,25\end{array}$ & $\begin{array}{c}11,8 \pm \\
0,13\end{array}$ \\
\hline & & Кастрати & $\begin{array}{c}102,4 \pm \\
1,33 \\
\end{array}$ & $\begin{array}{c}126,8 \pm \\
0,98\end{array}$ & $\begin{array}{c}71,6 \pm \\
1,25\end{array}$ & $\begin{array}{c}90,7 \pm \\
1,54\end{array}$ & $\begin{array}{c}69,9 \pm \\
2,03\end{array}$ & $\begin{array}{c}71,5 \pm \\
0,88\end{array}$ & $\begin{array}{c}93,9 \pm \\
1,03\end{array}$ & $\begin{array}{c}97,5 \pm \\
0,69 \\
\end{array}$ & $\begin{array}{c}35,2 \pm \\
0,12\end{array}$ & $\begin{array}{c}36,7 \pm \\
0,15\end{array}$ & $\begin{array}{c}10,6 \pm \\
0,18\end{array}$ & $\begin{array}{c}12,4 \pm \\
0,18\end{array}$ \\
\hline & & Кнурці & $\begin{array}{c}101,3 \pm \\
2,06\end{array}$ & $\begin{array}{c}126,4 \pm \\
0,87\end{array}$ & $\begin{array}{c}70,3 \pm \\
2,05\end{array}$ & $\begin{array}{c}89,9 \pm \\
2,03\end{array}$ & $\begin{array}{c}69,4 \pm \\
0,89\end{array}$ & $\begin{array}{c}71,1 \pm \\
2,04\end{array}$ & $\begin{array}{c}94,2 \pm \\
2,01\end{array}$ & $\begin{array}{c}97,8 \pm \\
1,56\end{array}$ & $\begin{array}{c}34,0 \pm \\
0,12\end{array}$ & $\begin{array}{c}35,3 \pm \\
0,16\end{array}$ & $\begin{array}{c}10,7 \pm \\
0,31\end{array}$ & $\begin{array}{c}12,2 \pm \\
0,29\end{array}$ \\
\hline & & середньому & \begin{tabular}{|l|}
101,2 \\
\end{tabular} & 126,1 & 70,3 & 89,5 & 69,5 & 71,0 & 93,6 & 97,0 & 34,4 & 35,9 & 10,6 & 12,1 \\
\hline \multirow{4}{*}{ II } & \multirow{4}{*}{ M } & Свинки & \begin{tabular}{|c|}
$101,4 \pm$ \\
2,05 \\
\end{tabular} & $\begin{array}{c}127,1 \pm \\
1,33 \\
\end{array}$ & $\begin{array}{c}69,0 \pm \\
0,98\end{array}$ & $\begin{array}{c}87,3 \pm \\
0,88 \\
\end{array}$ & $\begin{array}{c}68,1 \pm \\
0,98 \\
\end{array}$ & $\begin{array}{c}68,7 \pm \\
1,07 \\
\end{array}$ & $\begin{array}{c}91,8 \pm \\
1,23 \\
\end{array}$ & \begin{tabular}{|c|}
$93,7 \pm$ \\
1,32 \\
\end{tabular} & $\begin{array}{c}35,2^{* *} \pm \\
0,32 \\
\end{array}$ & $\begin{array}{c}39,7 \pm \\
0,24 \\
\end{array}$ & \begin{tabular}{|c|}
$10,5 \pm$ \\
0,19 \\
\end{tabular} & $\begin{array}{c}11,6^{*} \pm \\
0,31 \\
\end{array}$ \\
\hline & & Кастрати & \begin{tabular}{|c|}
$99,8 \pm$ \\
0,99 \\
\end{tabular} & $\begin{array}{c}124,8 \pm \\
0,87 \\
\end{array}$ & $\begin{array}{c}69,1 \pm \\
0,87 \\
\end{array}$ & $\begin{array}{c}87,9 \pm \\
2,01 \\
\end{array}$ & $\begin{array}{c}69,2 \pm \\
0,49 \\
\end{array}$ & $\begin{array}{c}70,4 \pm \\
1,62 \\
\end{array}$ & $\begin{array}{c}93,0 \pm \\
0,69 \\
\end{array}$ & \begin{tabular}{|c|}
$94,2 \pm$ \\
0,98 \\
\end{tabular} & $\begin{array}{c}35,8 \pm \\
0,29 \\
\end{array}$ & $\begin{array}{c}40,3 \pm \\
0,11 \\
\end{array}$ & $\begin{array}{c}10,7^{\star *} \pm \\
0,31 \\
\end{array}$ & \begin{tabular}{|c|}
$12,6 \pm$ \\
0,28 \\
\end{tabular} \\
\hline & & Кнурці & \begin{tabular}{|c|}
$99,7 \pm$ \\
0,89
\end{tabular} & $\begin{array}{c}125,3 \pm \\
1,32 \\
\end{array}$ & $\begin{array}{c}68,6 \pm \\
2,05\end{array}$ & $\begin{array}{c}88,5 \pm \\
2,51\end{array}$ & $\begin{array}{c}68,8 \pm \\
1,08\end{array}$ & $\begin{array}{c}70,6 \pm \\
0,89 \\
\end{array}$ & $\begin{array}{c}93,6 \pm \\
1,23 \\
\end{array}$ & \begin{tabular}{|c|}
$95,2 \pm$ \\
2,34 \\
\end{tabular} & $\begin{array}{c}34,9 \pm \\
0,31\end{array}$ & $\begin{array}{l}38,9^{*} \\
\pm 0,23\end{array}$ & $\begin{array}{c}10,8 \pm \\
0,22\end{array}$ & $\begin{array}{c}12,5 \pm \\
0,31 \\
\end{array}$ \\
\hline & & B cepe & 100,3 & 125,7 & 68,9 & 87,9 & 68,7 & 69,9 & 92,8 & 94,4 & 35,3 & 39,6 & 10,7 & 12,2 \\
\hline \multirow{4}{*}{ III } & \multirow{4}{*}{ Л } & Свинки & \begin{tabular}{|c|}
$102,4 \pm$ \\
1,23 \\
\end{tabular} & $\begin{array}{c}127,4 \pm \\
0,69 \\
\end{array}$ & \begin{tabular}{|c|}
$72,6 \pm$ \\
0,89 \\
\end{tabular} & \begin{tabular}{|c|}
$91,3 \pm$ \\
1,31 \\
\end{tabular} & \begin{tabular}{|l|}
$70,9 \pm$ \\
0,67 \\
\end{tabular} & \begin{tabular}{|c|}
$71,7 \pm$ \\
1,32 \\
\end{tabular} & $\begin{array}{c}95,7 \pm \\
1,22 \\
\end{array}$ & $\begin{array}{c}99,4^{* *} \pm \\
0,88 \\
\end{array}$ & $\begin{array}{c}31,2^{* *} \pm \\
0,11 \\
\end{array}$ & $\begin{array}{c}32,8 \pm \\
0,14 \\
\end{array}$ & \begin{tabular}{|c|}
$11,9 \pm$ \\
0,17 \\
\end{tabular} & $\begin{array}{c}13,7^{* *} \pm \\
0,15 \\
\end{array}$ \\
\hline & & Кастрати & $\begin{array}{c}100,0 \pm \\
0,98 \\
\end{array}$ & $\begin{array}{c}125,3 \pm \\
2,15\end{array}$ & $\begin{array}{c}71,7 \pm \\
0,68\end{array}$ & $\begin{array}{c}91,2 \pm \\
1,28\end{array}$ & $\begin{array}{c}71,7 \pm \\
1,23 \\
\end{array}$ & $\begin{array}{c}72,8 \pm \\
0,69 \\
\end{array}$ & $\begin{array}{c}97,4 \pm \\
0,98 \\
\end{array}$ & $\begin{array}{c}101,4 \pm \\
2,31 \\
\end{array}$ & $\begin{array}{c}31,8 \pm \\
0,21 \\
\end{array}$ & $\begin{array}{c}33,6^{*} \pm \\
0,31\end{array}$ & $\begin{array}{c}12,3 \pm \\
0,09 \\
\end{array}$ & $\begin{array}{c}13,9 \pm \\
0,14\end{array}$ \\
\hline & & Кнурці & \begin{tabular}{|c|}
$102,7 \pm$ \\
1,22 \\
\end{tabular} & $\begin{array}{c}126,7 \pm \\
1,11 \\
\end{array}$ & $\begin{array}{c}73,5 \pm \\
2,06\end{array}$ & $\begin{array}{c}92,0 \pm \\
0,94 \\
\end{array}$ & $\begin{array}{c}71,6 \pm \\
2,31 \\
\end{array}$ & \begin{tabular}{|c|}
$72,6 \pm$ \\
2,45 \\
\end{tabular} & \begin{tabular}{|c|}
$97,9 \pm$ \\
2,04 \\
\end{tabular} & $\begin{array}{c}102,3 \pm \\
0,99 \\
\end{array}$ & $\begin{array}{c}31,3 \pm \\
0,31\end{array}$ & $\begin{array}{c}33,1 \pm \\
0,15\end{array}$ & $\begin{array}{c}12,4 \pm \\
0,19\end{array}$ & $\begin{array}{c}13,7 \\
\pm 0,14\end{array}$ \\
\hline & & В середньому & 101,9 & 126,5 & 72,6 & 91,5 & 71,4 & 72,4 & 97,0 & 101,0 & 31,4 & 33,2 & 12,2 & 13,8 \\
\hline \multirow{4}{*}{ IV } & \multirow{4}{*}{ ПМ } & Свинки & $\begin{array}{c}101,4 \pm \\
2,03\end{array}$ & $\begin{array}{c}125,8 \pm \\
2,07\end{array}$ & $\begin{array}{c}72,2 \pm \\
0,95\end{array}$ & $\begin{array}{c}90,8 \pm \\
1,58\end{array}$ & $\begin{array}{c}71,2 \pm \\
2,17\end{array}$ & \begin{tabular}{|c|}
$72,2 \pm$ \\
2,10 \\
\end{tabular} & $\begin{array}{c}95,1 \pm \\
2,06 \\
\end{array}$ & $\begin{array}{c}98,6 \pm \\
1,36\end{array}$ & $\begin{array}{c}30,1 \pm \\
0,14\end{array}$ & $\begin{array}{c}32,7 \pm \\
0,15\end{array}$ & $\begin{array}{c}11,7 \pm \\
0,12\end{array}$ & $\begin{array}{l}13,2^{* *} \\
\pm 0,18\end{array}$ \\
\hline & & Кастрати & \begin{tabular}{|c|}
$103,1 \pm$ \\
0,98 \\
\end{tabular} & $\begin{array}{c}126,7 \pm \\
1,69 \\
\end{array}$ & \begin{tabular}{|c}
$74,2 \pm$ \\
2,04 \\
\end{tabular} & \begin{tabular}{|c|}
$93,5 \pm$ \\
1,84 \\
\end{tabular} & \begin{tabular}{|c|}
$72,0 \pm$ \\
2,04 \\
\end{tabular} & $\begin{array}{c}73,8 \pm \\
1,10 \\
\end{array}$ & $\begin{array}{c}96,8 \pm \\
1,24 \\
\end{array}$ & $\begin{array}{c}99,5 \pm \\
1,07 \\
\end{array}$ & $\begin{array}{c}31,1 \pm \\
0,16\end{array}$ & $\begin{array}{c}33,8^{*} \pm \\
0,24\end{array}$ & $\begin{array}{c}11,8 \pm \\
0,25 \\
\end{array}$ & $\begin{array}{c}13,6 \pm \\
0,16 \\
\end{array}$ \\
\hline & & Кнурці & \begin{tabular}{|c|}
$103,7 \pm$ \\
2,21 \\
\end{tabular} & $\begin{array}{c}126,9 \pm \\
2,63\end{array}$ & $\begin{array}{c}74,2 \pm \\
1,68\end{array}$ & $\begin{array}{c}91,9 \pm \\
0,89\end{array}$ & $\begin{array}{c}71,6 \pm \\
1,74\end{array}$ & $\begin{array}{c}72,4 \pm \\
0,87 \\
\end{array}$ & $\begin{array}{c}96,7 \pm \\
1,08 \\
\end{array}$ & $\begin{array}{c}100,2 \pm \\
1,35 \\
\end{array}$ & $\begin{array}{l}30,5^{* *} \\
\pm 0,31 \\
\end{array}$ & $\begin{array}{c}33,2 \pm \\
0,21\end{array}$ & $\begin{array}{c}11,9 \pm \\
0,24 \\
\end{array}$ & $\begin{array}{c}13,5 \pm \\
0,15\end{array}$ \\
\hline & & В середньому & 102,7 & 126,4 & 73,6 & 92,1 & 71,6 & 72,8 & 96,2 & 99,4 & 30,6 & 33,2 & 11,8 & 13,4 \\
\hline \multirow{5}{*}{ V } & \multirow{4}{*}{ ЧБП } & Свинки & $\begin{array}{c}100,3 \pm \\
2,03\end{array}$ & $\begin{array}{c}124,9 \pm \\
1,59\end{array}$ & $\begin{array}{c}69,6 \pm \\
1,69\end{array}$ & $\begin{array}{c}88,4 \pm \\
2,01\end{array}$ & $\begin{array}{c}69,4 \pm \\
0,92\end{array}$ & $\begin{array}{c}70,8 \pm \\
1,24\end{array}$ & $\begin{array}{c}94,5 \pm \\
1,09\end{array}$ & $\begin{array}{c}98,1 \pm \\
1,09\end{array}$ & $\begin{array}{l}29,8 \pm \\
10,25\end{array}$ & $\begin{array}{c}31,9 \pm \\
0,24\end{array}$ & $\begin{array}{c}11,6 \pm \\
0,18\end{array}$ & $\begin{array}{l}13,1^{* *} \\
\pm 0,17\end{array}$ \\
\hline & & Кастрати & $\begin{array}{c}101,4 \pm \\
1,34\end{array}$ & $\begin{array}{c}125,7 \pm \\
2,06\end{array}$ & $\begin{array}{c}72,2 \pm \\
1,63\end{array}$ & $\begin{array}{c}90,8 \pm \\
1,73\end{array}$ & $\begin{array}{c}71,2 \pm \\
1,62\end{array}$ & $\begin{array}{c}72,2 \pm \\
0,76\end{array}$ & $\begin{array}{c}96,3 \pm \\
2,36\end{array}$ & $\begin{array}{c}99,2^{* *} \pm \\
0,79\end{array}$ & \begin{tabular}{|c|}
$30,3 \pm$ \\
0,32
\end{tabular} & $\begin{array}{l}33,3^{* *} \\
\pm 0,19\end{array}$ & $\begin{array}{c}11,8 \pm \\
0,09\end{array}$ & $\begin{array}{c}13,3 \pm \\
0,26\end{array}$ \\
\hline & & Кнурці & \begin{tabular}{|c|}
$101,8 \pm$ \\
0,95 \\
\end{tabular} & $\begin{array}{c}126,1 \pm \\
1,92 \\
\end{array}$ & \begin{tabular}{|c|}
$71,8 \pm$ \\
0,92 \\
\end{tabular} & $\begin{array}{c}90,0 \pm \\
1,81 \\
\end{array}$ & \begin{tabular}{|c|}
$70,5 \pm$ \\
2,06 \\
\end{tabular} & $\begin{array}{c}71,4 \pm \\
1,46 \\
\end{array}$ & \begin{tabular}{|c|}
$96,8 \pm$ \\
0,81 \\
\end{tabular} & $\begin{array}{c}99,8 \pm \\
1,61 \\
\end{array}$ & $\begin{array}{l}30,2^{* *} \\
\pm 0,19 \\
\end{array}$ & $\begin{array}{c}33,1 \pm \\
0,13\end{array}$ & $\begin{array}{c}11,6 \pm \\
0,13\end{array}$ & $\begin{array}{c}13,2 \pm \\
0,24\end{array}$ \\
\hline & & В середньому & 101,2 & 125,6 & 71,2 & 89,7 & 70,4 & 71,5 & 95,9 & 99,0 & 30,1 & 32,8 & 11,7 & 13,2 \\
\hline & \multicolumn{2}{|c|}{$\begin{array}{c}\text { В середньому по до- } \\
\text { сліду }\end{array}$} &, 5 & 126,1 & 71,3 & 90,1 & 70,3 & 71,5 & 5,1 & 8,2 & 2,4 & 34,9 & 1,4 & 13,0 \\
\hline
\end{tabular}

Довшими були півтуші свиней породи ландрас, а найкоротшими - миргородської породи, різниця склала 4,3$6,7 \mathrm{~cm}$.

Більш тонкий шпик був у свиней червоної білопоясої породи : 29,0-31,9 мм, найбільш близькими до них були підсвинки полтавської м'ясної породи -29,4-32,4мм. Збільшення середньодобових приростів до 1000 г не змінило закономірностей показників забійних якостей, отриманих при забої тварин із середньодобовими приростами 250-350 г. Кастрати в порівнянні 3 кнурцями мали коротші півтуші і відрізнялись як від свинок, так і від кнурців товстішим шпиком.

На основі одержаних експериментальних даних проведено дисперсійний аналіз впливу форм годівлі на забійні якості свиней. Факторна дисперсія, що характеризує мінливість показника, викликану впливом фрактору годівлі дорівнювала 0,72-0,79 при забої в 100 кг і 0,71-0,85 при забої в 125 кг. В середньому по досліду загальна дисперсія, що показує загальну мінливість ознаки при забої свиней живою масою 100 кг коливалась від 0,93 у свиней миргородської породи до 1,01 у полтавської м'ясної породи. Найбільшою частка впливу форми годівлі на забійний вихід спостерігалась у свиней м'ясних генотипів, зокрема у полтавської м'ясної 84,9-88,8\% та червоної білопоясої породи свиней $86,4-83,6 \%$. 
Таблиця 3

Забійні якості піддослідних свиней (середньодобовий приріст 800-1000 г)

\begin{tabular}{|c|c|c|c|c|c|c|c|c|c|c|c|c|c|c|}
\hline \multirow{2}{*}{ 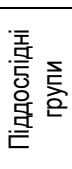 } & \multirow{2}{*}{$\begin{array}{l}\text { 흠 } \\
\text { 음 }\end{array}$} & \multirow{2}{*}{$\begin{array}{c}\text { Статева } \\
\text { належність } \\
\text { тварин }\end{array}$} & \multicolumn{2}{|c|}{$\begin{array}{l}\text { Передзабійна } \\
\text { маса, кг }\end{array}$} & \multicolumn{2}{|c|}{$\begin{array}{l}\text { Забійна маса, } \\
\text { кг }\end{array}$} & \multicolumn{2}{|c|}{$\begin{array}{l}\text { Забійний } \\
\text { вихід, \% }\end{array}$} & \multicolumn{2}{|c|}{$\begin{array}{c}\text { Довжина напівтуші, } \\
\text { см }\end{array}$} & \multicolumn{2}{|c|}{$\begin{array}{c}\text { Товщина шпику над } \\
6-7 \text { грудним } \\
\text { хребцем мм } \\
\end{array}$} & \multicolumn{2}{|c|}{ Маса окосту, кг } \\
\hline & & & $\begin{array}{c}100 \\
\mathrm{~K} \Gamma\end{array}$ & $\begin{array}{l}125 \\
\mathrm{~K} \Gamma\end{array}$ & $\begin{array}{c}100 \\
\mathrm{~K} \Gamma\end{array}$ & $\begin{array}{l}125 \\
\mathrm{~K} \Gamma\end{array}$ & $\begin{array}{c}100 \\
\mathrm{~K} \Gamma\end{array}$ & $\begin{array}{c}125 \\
\mathrm{~K} \Gamma\end{array}$ & 100 кг & 125 кг & 100 кг & 125 кг & $\begin{array}{l}100 \\
\mathrm{~K} \Gamma\end{array}$ & 125 кг \\
\hline \multirow{4}{*}{ I } & \multirow{4}{*}{ ВБ } & Свинки & $\begin{array}{c}101,4 \pm \\
1,26\end{array}$ & $\begin{array}{c}125,1 \pm \\
0,89\end{array}$ & $\begin{array}{c}71,7 \pm \\
0,89\end{array}$ & $\begin{array}{l}89,8 \pm \\
2,08\end{array}$ & $\begin{array}{l}70,7 \pm \\
2,03\end{array}$ & $\begin{array}{c}71,8 \pm \\
0,98\end{array}$ & $\begin{array}{c}94,2 \pm \\
1,09\end{array}$ & $\begin{array}{c}96,4 \pm \\
0,98\end{array}$ & $\begin{array}{c}32,7 \pm \\
0,15\end{array}$ & $\begin{array}{c}34,5^{\star *} \pm \\
0,22\end{array}$ & $\begin{array}{c}10,6 \pm \\
0,09\end{array}$ & $\begin{array}{c}12,1 \pm \\
0,09\end{array}$ \\
\hline & & Кастрати & $\begin{array}{c}100,9 \pm \\
2,03\end{array}$ & $\begin{array}{c}125,8 \pm \\
2,08 \\
\end{array}$ & $\begin{array}{c}72,4 \pm \\
1,25 \\
\end{array}$ & $\begin{array}{c}92,1 \pm \\
0,99 \\
\end{array}$ & $\begin{array}{c}71,7 \pm \\
0,89 \\
\end{array}$ & $\begin{array}{c}72,9 \pm \\
0,67 \\
\end{array}$ & $\begin{array}{c}96,4 \pm \\
0,99 \\
\end{array}$ & $\begin{array}{c}99,2 \pm \\
0,58 \\
\end{array}$ & $\begin{array}{c}31,2 \pm \\
0,26 \\
\end{array}$ & $\begin{array}{c}34,1 \pm \\
0,16 \\
\end{array}$ & $\begin{array}{c}11,6 \pm \\
0,19 \\
\end{array}$ & \begin{tabular}{|c|}
$13,3 \pm$ \\
0,21 \\
\end{tabular} \\
\hline & & Кнурці & $\begin{array}{c}100,8 \pm \\
1,08\end{array}$ & $\begin{array}{c}124,9 \pm \\
2,38\end{array}$ & $\begin{array}{c}71,4 \pm \\
0,69\end{array}$ & $\begin{array}{c}90,6 \pm \\
1,69\end{array}$ & $\begin{array}{c}70,8 \pm \\
1,23\end{array}$ & $\begin{array}{c}72,5 \pm \\
0,98\end{array}$ & $\begin{array}{c}95,1 \pm \\
1,22\end{array}$ & $\begin{array}{c}99,3 \pm \\
1,12\end{array}$ & $\begin{array}{c}32,6 \pm \\
0,14\end{array}$ & $\begin{array}{c}34,6 \pm \\
0,18\end{array}$ & $\begin{array}{c}11,0 \pm \\
0,31\end{array}$ & $\begin{array}{c}12,4 \pm \\
0,09\end{array}$ \\
\hline & & B cepe & 101,4 & 125,4 & 71,9 & 90,8 & 70,9 & 72,4 & 94,9 & 98,0 & 33,2 & 35,0 & 10,8 & 12,4 \\
\hline \multirow{4}{*}{$\|$} & \multirow{4}{*}{ M } & Свинки & $\begin{array}{c}99,8 \pm \\
1,05 \\
\end{array}$ & $\begin{array}{c}125,0 \pm \\
1,94\end{array}$ & $\begin{array}{c}69,2 \pm \\
1,24 \\
\end{array}$ & $\begin{array}{c}87,6 \pm \\
0,88\end{array}$ & $\begin{array}{c}69,4 \pm \\
1,23 \\
\end{array}$ & $\begin{array}{c}70,1 \pm \\
0,99 \\
\end{array}$ & $\begin{array}{c}93,2 \pm \\
0,69 \\
\end{array}$ & $\begin{array}{c}94,4 \pm \\
0,89 \\
\end{array}$ & $\begin{array}{c}33,8^{* *} \pm \\
0,26\end{array}$ & $\begin{array}{c}38,5 \pm \\
0,13\end{array}$ & $\begin{array}{c}10,7 \pm \\
0,21\end{array}$ & $\begin{array}{c}11,9^{\star *} \pm \\
0,16 \\
\end{array}$ \\
\hline & & Кастрати & $\begin{array}{c}101,4 \pm \\
2,31 \\
\end{array}$ & $\begin{array}{c}126,9 \pm \\
1,36\end{array}$ & \begin{tabular}{|c|}
$71,6 \pm$ \\
0,34 \\
\end{tabular} & $\begin{array}{c}91,1 \pm \\
1,11 \\
\end{array}$ & $\begin{array}{c}70,6 \pm \\
1,39 \\
\end{array}$ & $\begin{array}{c}71,8 \pm \\
0,69\end{array}$ & $\begin{array}{c}94,4^{*} \pm \\
0,59\end{array}$ & $\begin{array}{c}95,1 \pm \\
0,64\end{array}$ & $\begin{array}{c}34,7 \pm \\
0,32\end{array}$ & $\begin{array}{c}39,3 \pm \\
0,24\end{array}$ & $\begin{array}{c}11,0^{*} \pm \\
0,16\end{array}$ & $\begin{array}{c}13,0 \pm \\
0,21\end{array}$ \\
\hline & & Кнурці & $\begin{array}{c}101,1 \pm \\
2,11\end{array}$ & $\begin{array}{c}126,4 \pm \\
0,94\end{array}$ & $\begin{array}{c}70,9 \pm \\
1,03\end{array}$ & $\begin{array}{c}91,0 \pm \\
2,09\end{array}$ & $\begin{array}{c}70,2 \pm \\
1,69\end{array}$ & $\begin{array}{c}72,0 \pm \\
1,09\end{array}$ & $\begin{array}{c}94,5 \pm \\
1,23\end{array}$ & $\begin{array}{c}96,6 \pm \\
0,65\end{array}$ & $\begin{array}{c}33,5 \pm \\
0,29\end{array}$ & $\begin{array}{c}38,1^{* *} \pm \\
0,16\end{array}$ & $\begin{array}{c}11,1 \pm \\
0,21\end{array}$ & $\begin{array}{c}12,7 \pm \\
0,14\end{array}$ \\
\hline & & B cep & 100,8 & 126,1 & 70,6 & 89,9 & 70,0 & 71,3 & 94,0 & $95,4 \pm$ & 34,0 & 38,6 & 10,9 & 12,5 \\
\hline \multirow{4}{*}{ III } & \multirow{4}{*}{ Л } & Свинки & $\begin{array}{c}101,2 \pm \\
0,99\end{array}$ & $\begin{array}{c}126,1 \pm \\
0,87\end{array}$ & $\begin{array}{c}73,2 \pm \\
1,05\end{array}$ & $\begin{array}{c}92,2 \pm \\
1,36\end{array}$ & $\begin{array}{c}72,3 \pm \\
2,09\end{array}$ & $\begin{array}{c}73,1 \pm \\
0,36\end{array}$ & $\begin{array}{c}97,1 \pm \\
0,64\end{array}$ & $\begin{array}{c}100,2 \pm \\
2,03\end{array}$ & $\begin{array}{c}30,0 \pm \\
0,19\end{array}$ & $\begin{array}{c}31,8^{*} \pm \\
0,24\end{array}$ & $\begin{array}{c}12,1 \pm \\
0,16\end{array}$ & $\begin{array}{c}14,0^{*} \pm \\
0,09\end{array}$ \\
\hline & & Кастрати & $\begin{array}{c}100,6 \pm \\
1,58\end{array}$ & $\begin{array}{c}126,8 \pm \\
1,69\end{array}$ & $\begin{array}{c}73,6 \pm \\
0,66\end{array}$ & $\begin{array}{c}94,2 \pm \\
1,25\end{array}$ & $\begin{array}{c}73,1 \pm \\
2,09\end{array}$ & $\begin{array}{c}74,3 \pm \\
0,94\end{array}$ & $\begin{array}{c}98,9 \pm \\
0,69\end{array}$ & $\begin{array}{c}102,4 \pm \\
1,09 \\
\end{array}$ & $\begin{array}{c}30,8 \pm \\
0,11\end{array}$ & $\begin{array}{c}32,8 \pm \\
0,16\end{array}$ & $\begin{array}{c}12,6 \pm \\
0,09\end{array}$ & $\begin{array}{c}14,3 \pm \\
0,25 \\
\end{array}$ \\
\hline & & Кнурці & $\begin{array}{c}102,3 \pm \\
0,89\end{array}$ & $\begin{array}{c}125,8 \pm \\
2,38\end{array}$ & $\begin{array}{c}74,7 \pm \\
0,59\end{array}$ & $\begin{array}{c}93,2 \pm \\
0,99\end{array}$ & $\begin{array}{c}73,0 \pm \\
0,89\end{array}$ & $\begin{array}{c}74,1 \pm \\
0,94\end{array}$ & $\begin{array}{c}98,9 \pm \\
1,23\end{array}$ & $\begin{array}{c}103,8 \pm \\
0,98\end{array}$ & $\begin{array}{c}30,0^{*} \pm \\
0,23\end{array}$ & $\begin{array}{c}32,4 \pm \\
0,22\end{array}$ & $\begin{array}{c}12,8 \pm \\
0,23\end{array}$ & $\begin{array}{c}13,9 \pm \\
0,27\end{array}$ \\
\hline & & B cepe & 101,4 & 126,2 & 73,8 & 93,2 & 72,8 & 73,8 & 98,3 & 102,1 & 30,3 & 32,3 & 12,5 & 14,1 \\
\hline \multirow{4}{*}{ IV } & \multirow{4}{*}{ ПМ } & Свинки & $\begin{array}{c}99,8 \pm \\
1,25\end{array}$ & $\begin{array}{c}124,8 \pm \\
2,18\end{array}$ & $\begin{array}{c}72,5 \pm \\
0,89\end{array}$ & $\begin{array}{c}91,9 \pm \\
1,22\end{array}$ & $\begin{array}{c}72,6 \pm \\
0,68\end{array}$ & $\begin{array}{c}73,6 \pm \\
0,69\end{array}$ & $\begin{array}{c}96,5^{\star *} \pm \\
1,23\end{array}$ & $\begin{array}{c}99,4 \pm \\
1,35\end{array}$ & $\begin{array}{c}28,9 \pm \\
0,12\end{array}$ & $\begin{array}{c}31,7^{\star} \pm \\
0,19\end{array}$ & $\begin{array}{c}11,9 \pm \\
0,15\end{array}$ & $\begin{array}{c}13,5 \pm \\
0,25\end{array}$ \\
\hline & & Кастрати & $\begin{array}{c}100,6 \pm \\
2,05\end{array}$ & $\begin{array}{c}126,8 \pm \\
2,31\end{array}$ & $\begin{array}{c}73,9 \pm \\
1,26 \\
\end{array}$ & $\begin{array}{c}95,4 \pm \\
1,06 \\
\end{array}$ & $\begin{array}{c}73,4 \pm \\
0,69 \\
\end{array}$ & $\begin{array}{c}75,3 \pm \\
1,23 \\
\end{array}$ & $\begin{array}{c}98,3 \pm \\
0,69 \\
\end{array}$ & $\begin{array}{c}100,5 \pm \\
0,89 \\
\end{array}$ & $\begin{array}{c}30,2^{*} \pm \\
0,18 \\
\end{array}$ & $\begin{array}{c}33,0 \pm \\
0,21 \\
\end{array}$ & \begin{tabular}{|c|}
$12,1 \pm$ \\
0,21 \\
\end{tabular} & $\begin{array}{c}14,0 \pm \\
0,14 \\
\end{array}$ \\
\hline & & Кнурці & $\begin{array}{c}100,4 \pm \\
1,23\end{array}$ & $\begin{array}{c}125,3 \pm \\
2,09\end{array}$ & $\begin{array}{c}73,3 \pm \\
2,31\end{array}$ & $\begin{array}{c}92,5 \pm \\
1,26\end{array}$ & $\begin{array}{c}73,0 \pm \\
1,61\end{array}$ & $\begin{array}{c}73,8 \pm \\
0,84\end{array}$ & $\begin{array}{c}97,7^{*} \pm \\
1,08\end{array}$ & $\begin{array}{c}101,7^{*} \pm \\
1,25\end{array}$ & $\begin{array}{c}29,3 \pm \\
0,26\end{array}$ & $\begin{array}{c}32,5^{\star *} \pm \\
0,14\end{array}$ & $\begin{array}{c}12,3 \pm \\
0,31\end{array}$ & $\begin{array}{c}13,7^{\star *} \pm \\
0,31\end{array}$ \\
\hline & & В середньому & 100,3 & 125,6 & 73,2 & 93,3 & 73,0 & 74,3 & 97,5 & 100,5 & 29,4 & 32,4 & 12,1 & 13,7 \\
\hline \multirow{4}{*}{ V } & \multirow{4}{*}{ ЧБП } & Свинки & $\begin{array}{c}100,5 \pm \\
0,98\end{array}$ & $\begin{array}{c}124,8 \pm \\
1,68\end{array}$ & $\begin{array}{c}71,1 \pm \\
0,87\end{array}$ & $\begin{array}{c}90,1 \pm \\
0,89\end{array}$ & $\begin{array}{c}70,8 \pm \\
2,09\end{array}$ & $\begin{array}{c}72,2 \pm \\
1,26\end{array}$ & $\begin{array}{c}95,9 \pm \\
1,06\end{array}$ & $\begin{array}{c}98,9 \pm \\
0,98\end{array}$ & $\begin{array}{c}28,6 \pm \\
0,24\end{array}$ & $\begin{array}{c}30,9^{* *} \pm \\
0,15\end{array}$ & $\begin{array}{c}11,8 \pm \\
0,09\end{array}$ & $\begin{array}{c}13,4 \pm \\
0,14\end{array}$ \\
\hline & & Кастрати & $\begin{array}{c}101,2 \pm \\
1,26\end{array}$ & $\begin{array}{c}126,3 \pm \\
1,95\end{array}$ & $\begin{array}{c}73,5 \pm \\
0,88\end{array}$ & $\begin{array}{c}93,0 \pm \\
1,03\end{array}$ & $\begin{array}{c}72,6 \pm \\
0,84\end{array}$ & $\begin{array}{c}73,6 \pm \\
0,69\end{array}$ & $\begin{array}{c}97,7^{* *} \pm \\
2,01\end{array}$ & $\begin{array}{c}100,2^{*} \pm \\
0,61\end{array}$ & $\begin{array}{c}29,4 \pm \\
0,16\end{array}$ & $\begin{array}{c}32,5 \pm \\
0,21\end{array}$ & $\begin{array}{c}12,1^{*} \pm \\
0,18\end{array}$ & $\begin{array}{c}13,7 \pm \\
0,09\end{array}$ \\
\hline & & Кнурці & $\begin{array}{c}100,6 \pm \\
1,22\end{array}$ & $\begin{array}{c}125,9 \pm \\
0,98\end{array}$ & $\begin{array}{c}72,3 \pm \\
2,11 \\
\end{array}$ & $\begin{array}{c}91,7 \pm \\
2,06 \\
\end{array}$ & $\begin{array}{c}71,9 \pm \\
1,23\end{array}$ & $\begin{array}{c}72,8 \pm \\
1,61 \\
\end{array}$ & $\begin{array}{c}97,8 \pm \\
0,59 \\
\end{array}$ & $\begin{array}{c}101,3 \pm \\
0,39 \\
\end{array}$ & $\begin{array}{c}29,0^{*} \pm \\
0,31 \\
\end{array}$ & $\begin{array}{c}32,4 \pm \\
0,18 \\
\end{array}$ & $\begin{array}{c}11,9 \pm \\
0,38\end{array}$ & $\begin{array}{c}13,4^{* *} \pm \\
0,21\end{array}$ \\
\hline & & В середньому & 100,8 & 125,7 & 72,3 & 91,6 & 71,8 & 72,9 & 97,1 & 100,1 & 29,0 & 31,9 & 11,9 & 13,5 \\
\hline & \multicolumn{2}{|c|}{$\begin{array}{c}\text { В середньому по } \\
\text { досліду }\end{array}$} & 100,9 & 125,8 & 72,4 & 91,8 & 71,7 & 72,9 & 96,4 & 99,2 & 31,2 & 34,1 & 11,6 & 13,3 \\
\hline
\end{tabular}

Висновки. Результати забою засвідчили перевагу м'ясних генотипів над представниками сальних і м'ясосальних порід за показниками забійного виходу, довжини напівтуші, товщини шпику та маси окосту.

В сучасних умовах виробництва свинини відгодівля тварин потребує врахування певних проблем, пов'язаних із

впливом умов утримання, повноцінної годівлі, статі та результативності виробництва - середньодобові прирости, товщину шпику, витрати корму на одиницю продукції. Відгодівлю свиней різної статі необхідно організовувати відповідно до їх потреби у поживних речовинах.

\section{Список використаної літератури:}

1. Волощук В. М., Василів А.П. Відгодівельні, забійні та м'ясні якості підсвинків м'ясних порід. Свинарство: міжвідомчий тематичний науковий збірник Інституту свинарства і АПВ НААН. 2013. Вип. 62. С. 8-13.

2. Акімов С. Основні напрями подальшої роботи по вдосконаленню свиней полтавської та української м'ясних порід. Тваринництво України. №5. 2002 С.23-24.

3. Волощук В.М. Свинарство: монографія. Київ: Аграрна наука, 2014, 592 с.

4. Šprysl M., Čítek J., Stupka R. [et al.] The significance of the effects influencing the reproductive performance in pigs. Research in pig breeding. 2012. Vol. 6(1), P. 54-58.

5. Нарижна О.Л. Забійні якості чистопорідного та помісного молодняку, одержаного при поєднанні свиноматок великої білої породи з термінальними і чистопорідними кнурами різних генотипів. Свинарство: міжвідомчий тематичний науковий збірник Інституту свинарства і АПВ НААН. 2014. Вип. 65. С. 303-307.

6. Huang, Y.H., Lee, Y.P., Yang, T.S. and Roan S.W., 2003. Effects of Sire Breed on the Subsequent Reproductive Per- 
formances of Landrace Sows. Asian Australasian Journal of Animal Sciences, issue 16(4), p. $7 . \quad$ DOI: https://doi.org/10.5713/ajas.2003.489

7. Шебанін П. О. Технологічні та селекційно-генетичні фактори підвищення продуктивності свиней: автореф. дис. ... канд. с.-г. наук: 06.02.04. Миколаїв, 2016. 26 с.

8. Knecht D., Srodon S. and Duziński K., 2015. Breed on selected reproductive performance parameters of sows. Arch. Anim. Breed, issue 58, pp. 49-56.

9. Lazarevich A. N., Efimova L. V., Ivanova O. V. Effectiveness analysis of crossbreding the hybrid sows with thoroughbred and terminal sires. In the World of Scientific Discoveries, Series B. 2017. № 2. P. 16-32.

10. Ushakova S. Influence of boars of different breeds on reproductive qualities of sows in multipedigree crossbreeding. Visnyk Agrarnoi Nauky. 2016, issue. 94 (2). P. 68-69.

11. Халак В., Ференц Л., Стадницька О. Відгодівельні та м'ясні якості молодняку свиней різних поєднань. Агробізнес сьогодні. 2016. № 14. С. 14-15.

12. Рибалко В. П., Нагаєвич В. М. Створення популяції червоно-поясних свиней м'сного напрямку продуктивності. Вісник Полтавського державного сільськогосподарського інституту. №6. 2001. С.59-61.

13. Пелих В. Г., Ушакова С. В. Динаміка росту молодняку свиней різних генотипів. Науково-технічний бюлетень. 2016. № 115. С. 169-175.

14. Brent G. The Pigman's Handbook of Problem Solving. 2010. 192 c. (Crowood Press; 1 edition).

15. Zamaratskaia G., Rasmussenb M. K.. Immunocastration of male pigs - situation today. Procedia food science, vol. 5, 2015, pp. 324-327. DOI: https://doi.org/10.1016/j.profoo.2015.09.064.

\section{References:}

1. Voloshhuk, V. M. and Vasy'liv A. P., 2013. Vidgodivel'ni, zabijni ta m'yasni yakosti pidsvy’nkiv m'yasny`x porid [Fattening, slaughter and meat qualities of pigs of meat breeds]. Svy'narstvo: mizhvidomchy`j tematy'chny’j naukovy j zbirny`k Insty tutu svy'narstva i APV NAAN, issue 62, pp. 8-13.

2. Akimov, S., 2002. Osnovni napryamy' podal'shoyi roboty’ po vdoskonalennyu svy`nej poltavs 'koyi ta ukrayins`koyi m'yasny'x porid [The main directions of further work on the improvement of pigs of Poltava and Ukrainian meat breeds]. Tvary`nny' cztvo Ukrayiny', no 5, pp.23-24.

3. Voloshhuk, V. M., 2014. Svynarstvo: monohrafiia [Pig breeding: monograph]. Kyiv: Ahrarna nauka.

4. Šprysl M., Čítek J., Stupka R. [et al.]. 2012. The significance of the effects influencing the reproductive performance in pigs. Research in pig breeding. Vol. 6(1), pp. 54-58.

5. Nary zhna O. L., 2014. Zabijni yakosti chy'stoporidnogo ta pomisnogo molodnyaku, oderzhanogo pry poyednanni svy nomatok vely koyi biloyi porody' z terminal'ny'my' i chy'stoporidny'my' knuramy` rizny'x genoty' piv [Slaughter qualities of purebred and local young animals obtained by combining sows of large white breed with terminal and purebred boars of different genotypes]. Svy narstvo: mizhvidomchy”j tematy chny`j naukovy`j zbirny`k Insty` tutu svy`narstva i APV NAAN, issue 65, pp. 303-307.

6. Huang, Y. H., Lee, Y. P., Yang, T. S. and Roan S. W., 2003. Effects of Sire Breed on the Subsequent Reproductive Performances of Landrace Sows. Asian Australasian Journal of Animal Sciences, issue 16(4), p. 7, DOI: https://doi.org/10.5713/ajas.2003.489

7. Shebanin, P. O., 2016. Technological and selection-genetic factors to increase pig productivity. Abstract of Ph.D. dissertation. Mykolayiv.

8. Knecht, D., Srodon, S. and Duziński, K., 2015. Breed on selected reproductive performance parameters of sows. Arch. Anim. Breed, issue 58, pp. 49-56.

9. Lazarevich, A. N., Efimova, L. V. and Ivanova, O. V., 2017. Effectiveness analysis of crossbreding the hybrid sows with thoroughbred and terminal sires. In the World of Scientific Discoveries, Series B. № 2. P. 16-32.

10. Ushakova, S., 2016. Influence of boars of different breeds on reproductive qualities of sows in multipedigree crossbreeding. Visnyk Agrarnoi Nauky. issue. 94 (2). P. 68-69.

11. Halak, V., Ferenc, L. and Stadnytska, O., 2016. Vidgodivel'ni ta m'yasni yakosti molodnyaku svy'nej rizny'x poyednan` [Fattening and meat qualities of young pigs of different combinations]. Agrobiznes s'ogodni, no 14, pp.14-15.

12. Rybalko, V. P. and Nagaevich, V. M., 2001. Stvorennya populyaciyi chervono-poyasny`x svy'nej m'snogo napryamku produkty'vnosti [Creating a population of red-belt pigs with a low productivity direction]. Visny'k Poltavs'kogo derzhavnogo sil’s'kogospodars'kogo insty`tutu, no 6, pp.59-61.

13. Pelykh, V. G., 2016. Dy’namika rostu molodnyaku svy`nej rizny`x genoty`piv [Dynamics of growth of young pigs of different genotypes]. Naukovo-texnichny’j byuleten', no 115, pp. 169-175.

14. Brent G. The Pigman's Handbook of Problem Solving, 2010, 192. (Crowood Press; 1 edition).

15. Zamaratskaia G. and Rasmussenb M. K., 2015. Immunocastration of male pigs - situation today. Procedia food science, vol. 5, pp. 324-327. DOI: https://doi.org/10.1016/j.profoo.2015.09.064.

Birta Habriella Oleksandrivna, Doctor of Agricultural Sciences, Professor

Burhu Yurii Georgiyovich, Ph.D. of Agricultural Sciences, Associate Professor

Floka Liudmyla Valeriivna, Ph.D. of Agricultural Sciences, Associate Professor

Horiachova Olena Oleksandrivna, Ph.D. of Technical Sciences, Associate Professor

Khmelnytska Yevheniia Viktorivna, Ph.D. of Technical Sciences, Associate Professor

Poltava University of economics and trade (Poltava, Ukraine) 


\section{Slaughter qualities of pigs different genotypes}

The article explores the slaughter and meat-and-fat qualities of animals of different genotypes. The following indicators were determined: weight; slaughter mass; slaughter meat yield; half length; fat thickness; the area of the "muscular cell"; the meat and fat yield in the carcass, the morphological composition of the carcasses, the mass of muscle tissue. The experiments used purebred pigs of large white breed, Myrhorod, Poltava meat, landras and red white-bellied meat of pigs. The slaughter and meat-greasy qualities of the animals were determined by the following indicators: weight; slaughter mass; slaughter meat yield; half length; fat thickness; the area of the "muscular cell"; meat and fat in the carcass. The studies were carried out in accordance with standard guidelines. The morphological composition of the carcasses was studied by boning the right hemisphere. Muscle mass was determined by the difference between the mass of the hemisphere and the total mass of fat and bone. On the basis of the obtained experimental data, the variance analysis of the influence of feeding forms on slaughter quality of pigs was carried out. On average, the total dispersion showing the total variability of the trait in slaughtering pigs with live weight of $100 \mathrm{~kg}$ ranged from 0.93 in pigs of Myrhorod breed to 1.01 in Poltava meat breed. The largest proportion of the impact of the feeding form on the slaughter output was observed in pigs of meat genotypes, in particular in Poltava meat 84.9-88.8\% and red white-bellied pig breed 86.4-83.6\%. The results of slaughter showed the predominance of meat genotypes over the representatives of sebaceous and meat-sebaceous species in terms of slaughter output, half-carcass length, thickness of the spike and weight of the surrounding area. In modern conditions of pork production, animal fattening requires taking into account certain problems related to the influence of housing conditions, full feeding, sex and production efficiency - average daily gains, fat thickness, feed costs per unit of output. Fattening of pigs of different sexes should be organized according to their need for nutrients.

Key words: slaughter, quality, morphological composition, genotype, feeding, pig breeding

Дата надходження до редакції: 06.10.2021 p. 